\title{
Autoradiographic Study on the Incorporation of Carbon-14 Labeled Formate and Adenine into Nucleic Acid in Blood-forming Cells
}

\author{
By \\ Bunsuke OSOGOE and Masako YANAGI \\ Department of Anatomy, Kawasaki Medical School, \\ Kurashiki 701-01, Japan \\ -Received for Publication, November 16, 1981-
}

Key words: Blood-forming cells, DNA labeling, $\left[{ }^{14} \mathrm{C}\right]$ formate, $\left[{ }^{14} \mathrm{C}\right]$ adenine, autoradiography

Summary: The incorporation of $\left[{ }^{14} \mathrm{C}\right]$ formate and $\left[8{ }^{-14} \mathrm{C}\right]$ adenine into nucleic acid in blood-forming cells was studied by the autoradiographic technique. The isotopic markers were injected subcutaneously into young rats weighing from 100 to $150 \mathrm{~g}$ three times every 24 hours and the animals were examined 3 hours after the last injection.

In the case of $\left[{ }^{14} \mathrm{C}\right]$ formate injection, erythroblasts exhibited extremely strong labeling in contrast to weaker labeling of other blood-forming cells. In the case of $\left[{ }^{14} \mathrm{C}\right]$ adenine administration, on the other hand, immature cells of the granuclocytic series as well as immature reticulum cells (proliferating cells of reticular tissue) were much more heavily labeled than were other blood-forming cells, particularly the erythroblasts which revealed weak or no labeling. By digestion or extraction of DNA, RNA or both from cells with DNase, RNase or hot $10 \%$ perchloric acid treatment, respectively, it was confirmed that the observed heavy labeling of any type of cells with either $\left[{ }^{14} \mathrm{C}\right]$ formate or $\left[{ }^{14} \mathrm{C}\right]$ adenine was due chiefly to incorporation of the radioactive materials into nuclear DNA.

The present results are discussed together with the findings of earlier studies on lymphoid cells which indicate that, in certain cell types, the patterns of $\left[{ }^{3} \mathrm{H}\right]$ deoxycytidine labeling differ considerably from the corresponding patterns of $\left.{ }^{3} \mathrm{H}\right]$ deoxycytidine labeling. The present and earlier findings provide evidence to substantiate that, among blood-forming cells, there are considerable variations in the labeling patterns of nuclear DNA depending on differences in the radioactive DNA precursors used as well as in the cell types.

Earlier autoradiographic studies on lymphoid cells have revealed that some types of lymphocytes, such as cortical thymocytes, germinal-center cells and bone marrow lymphocytes, are much more heavily labeled with $\left[{ }^{3} \mathrm{H}\right]$ deoxycytidine $\left(\left[{ }^{3} \mathrm{H}\right] \mathrm{dCyd}\right)$ than with $\left[{ }^{3} \mathrm{H}\right]$ thymidine
( $\left[{ }^{3} \mathrm{H}\right] \mathrm{dThd}$ ) (Osogoe et al., 1973; Amano and Osogoe, 1975; Osogoe and Miyamoto, 1979a). On the other hand, large lymphocytes which occur outside the germinal centers, particularly pyroninophilic blast cells (or immunoblasts), have been shown to exhibit far stronger labeling with 
$\left[{ }^{3} \mathrm{H}\right] \mathrm{dThd}$ than with $\left[{ }^{3} \mathrm{H}\right] \mathrm{dCyd}$ (Osogoe and Miyamoto, 1979a, b; Osogoe and Okada, 1980). It is of particular interest that the labeling patterns of lymphoid cells vary considerably depending on differences in the radioactive DNA precursors used as well as in the cell types.

The purpose of the present study was to extend the above findings for lymphoid cells to other types of blood-forming cells, using $\left[{ }^{14} \mathrm{C}\right]$ formate and $\left[{ }^{14} \mathrm{C}\right]$ adenine as radioactive precursors of nucleic acids. It has been reported by several authors that either $\left[{ }^{14} \mathrm{C}\right]$ formate or $\left[{ }^{14} \mathrm{C}\right]$ adenine is incorporated into the nucleic acids, DNA in particular, of bone marrow cells to a considerable extent (Lajtha, 1954; Totter, 1954; Thomas and Locht, Jr., 1957), as well as into purine nucleotides of leukemic and normal circulating leukocytes (Scott, 1962 ; Schwarzmeier, 1974; Brosh et al., 1976). However, the labeling patterns of individual types of blood-forming cells with $\left[{ }^{14} \mathrm{C}\right]$ formate and $\left[{ }^{14} \mathrm{C}\right]$ adenine at the cellular level remain unknown.

\section{Materials and Methods}

Young male rats of the Wistar strain weighing from 100 to $150 \mathrm{~g}$ were used in the present experiments. One group (5 rats) was injected subcutaneously with $\left[{ }^{14} \mathrm{C}\right]$ formate $\left(\left[{ }^{14} \mathrm{C}\right] \mathrm{HCOONa}\right.$; specific activity, $40-60 \mathrm{mCi}$ per mmole) at a dose of $1 \mu \mathrm{Ci}$ per $\mathrm{g}$ of body weight three times every 24 hours. Another group (5 rats) was similarly injected with $\left[8-{ }^{14} \mathrm{C}\right]$ adenine (specific activity, 40-60 $\mathrm{mCi}$ per mmole). The radiochemicals were purchased from New England Nuclear Corp., Boston, Mass., U.S. A.

At 3 hours after the last injection of the isotopic markers, the rats were sacrificed and the blood-forming organs, together with the liver, small intestine (jejunum), kidneys and adrenals, were removed for autoradiographic examination.
Both sections and smears were prepared from the blood-forming organs (thymus, lymph nodes, spleen and bone marrow), while the other organs were examined merely from tissue sections. The tissues were fixed in Carnoy's fluid and the smears in methyl alcohol. After embedding in paraffin, the tissues were cut serially at $4 \mu$ thick. The sections and smears were extracted in 5\% trichloroacetic acid at $4^{\circ} \mathrm{C}$ before the preparation of autoradiographs.

\section{Autoradiographic procedures}

Autoradiographs were made using Sakura NR-M2 liquid emulsion. The exposure time was 2-4 weeks for sections and 4-6 weeks for smears. The sections were stained with hemalum-eosin or methyl green-pyronine and the smears with Giemsa solution after photographic processing.

\section{DNase and RNase treatments}

Since formate and adenine are known to be incorporated into both DNA and RNA, confirmation of the incorporation of the radioactive materials into DNA was carried out with DNase I and RNase A (Worthington Biochemical Co., Freehold, New Jersey, U.S. A.) treatments as described by Amano (1962), before dipping in emulsion. In addition, both DNA and RNA were extracted by hot $10 \%$ perchloric acid treatment $\left(70^{\circ} \mathrm{C}\right.$ for $\left.20 \mathrm{~min}\right)$.

\section{Results}

Labeling patterns of blood-forming cells
with $\left[{ }^{14} \mathrm{C}\right]$ formate
The most striking feature of the
$\left[{ }^{14} \mathrm{C}\right]$ formate labeling of the blood-forming
cells was that carbon- 14 incorporation
took place to a far greater extent into
erythroblasts than into other types of
cells. In the splenic red pulp, numerous
heavily labeled erythroblasts were found
densely aggregated (Fig. $1 \mathrm{~A}, \mathrm{~B}$ ). Among 
the erythroblasts, the most intense labeling was observed at the polychromatic and orthochromatic stages (Fig. 2C). However, proerythroblasts and basophilic erythroblasts also exhibited fairly strong labeling.

After RNA had been extracted from the cells by RNase treatment, the label of the erythroblasts remained essentially unaltered, although there was a reduction in labeling intensity to some extent, and the silver grains became more distinctly localized over the nuclei of the erythroblasts (Fig. 1A, B). In contrast, the labeling intensity of these cells was reduced to a large extent after extraction of DNA from the cells by DNase treatment (Fig. 1C). After both DNA and RNA had been removed from the cells by treatment with hot perchloric acid, the label of the erythroblasts disappeared almost completely (Fig. 1D). It is apparent therefore that $\left[{ }^{14} \mathrm{C}\right]$ formate had been preferentially incorporated into the nuclear DNA of the erythroblasts.

The immature cells of the lymphocytic series and of the reticulum (or reticular) cells* were poorly labeled with $\left[{ }^{14} \mathrm{C}\right]$ formate (Fig. 2B). However, such types of cells as cortical thymocytes and germinalcenter cells exhibited relatively strong labeling compared to the scanty labeling of other types of lymphoid cells. The former cell types remained distinctly labeled even after RNA had been extracted with RNase treatment (Fig. 2A). After treatment with either DNase or hot perchloric acid, the label of the lymphoid and reticular cells disappeared to a large extent. The labeling patterns of precursor cells of the granulocytic and monocytic series with $\left[{ }^{14} \mathrm{C}\right]$ formate were similar to those of cortical thymocytes and germinalcenter cells (Fig. 2C).

Other types of proliferating cells of the intestinal mucosa, liver, kidneys and adrenals revealed more scanty labeling with $\left[{ }^{14} \mathrm{C}\right]$ formate than did the precursor cells of the lymphocytic, granulocytic and monocytic series. Morever, the label of the former cell types disappeared to a large extent after treatment with either DNase or RNase, as well as with hot perchloric acid. As an exception, it is interesting to note that strong DNA labeling with $\left[{ }^{14} \mathrm{C}\right]$ formate was observed in small round cells resembling erythroblasts which occasionally appeared within the hepatic cinusoids as small cell clusters.

\section{Labeling patterns of blood-forming cells with $\left[{ }^{14} \mathrm{C}\right]$ adenine}

The patterns of $\left[{ }^{14} \mathrm{C}\right]$ adenine uptake by blood-forming cells were different from those of $\left[{ }^{14} \mathrm{C}\right]$ formate labeling. Immature cells of the granulocytic and monocytic series were intensely labeled with $\left[{ }^{14} \mathrm{C}\right]$ adenine in contrast to scanty labeling of other types of blood-forming cells, particularly the erythroblasts which revealed weak or no labeling (Fig. 3a-d). Among the former cell types, promyelocytes, myelocytes and metamyelocytes as well as premonocytes exhibited strong labeling even after RNase treatment (Fig. 3a-d). In addition to the above-mentioned cell types, immature reticulum (or reticular) cells (proliferating cells of the reticular tissue) of the spleen and lymph nodes, as well as of the bone marrow, were intensely labeled with $\left[{ }^{14} \mathrm{C}\right]$ adenine (Fig. $4 \mathrm{~A}, \mathrm{~B}$ ). Although to a much lesser extent, the cells of the lymphocytic series, cortical thymocytes and germinal-center in particular, were also labeled (Fig. 4A). Cells lining the hepatic sinusoids were unlabeled.

The labeling intensity of the lymphoid cells was greatly reduced by treatment with RNase, whereas the autoradiographic

\footnotetext{
* Special attention was directed towards immature reticulum cells (proliferating cells of reticular tissue) since these cells were heavily labeled with $\left[{ }^{14} \mathrm{C}\right]$ adenine.
} 
reaction of the reticulum cells remaiend almost unaltered after such treatment and the silver grians became more distinctly localized over the nuclei than previously (Fig. 4B). The label of the reticulum cells and that of the granulocytic and monocytic precursors vanished almost completely following treatment with either DNase or hot perchloric acid (Fig. 4C, D). These results indicate that the DNA of reticulum cells as well as that of granulocytic and monocytic precursors is intensely labeled with $\left[{ }^{14} \mathrm{C}\right]$ adenine.

Finally, it should be noted that some cell types of the connective tissue were as heavily labeled with $\left[{ }^{14} \mathrm{C}\right]$ adenine as the reticulum cells of the spleen and lymph nodes. Such cells were found in fairly large numbers in the lamina propria of the intestinal villi as well as in the interstitial spaces of the kidney.

\section{Discussion}

As outlined above, the labeling patterns of blood-forming cells with $\left[{ }^{14} \mathrm{C}\right]$ formate were essentially different from those with $\left[{ }^{14} \mathrm{C}\right]$ adenine. That is to say, $\left[{ }^{14} \mathrm{C}\right]$ formate incorporation was characterized by intense labeling of erythroblasts in contrast to weaker labeling of other types of bloodforming cells, whereas with $\left[{ }^{14} \mathrm{C}\right]$ adenine labeling, a clearly high rate of carbon-14 uptake occurred in myelocytes and premonocytes of the bone marrow as well as in immature reticulum cells of the spleen and lymph nodes, but the erythroblasts and immature lymphoid cells exhibited scanty or no labeling. It is important to emphasize here that the observed intense labeling of the above-mentioned cell types with either $\left[{ }^{14} \mathrm{C}\right]$ formate or $\left[{ }^{14} \mathrm{C}\right]$ adenine was due chiefly to incorporation of the radioactive materials into DNA. This was confirmed by the digestion or extraction tests of DNA, RNA or

Table 1. The effects of RNase, DNase and hot perchloric acid (PCA) treatments on labeling intensity of several types of blood-forming cells with $\left[{ }^{14} \mathrm{C}\right]$ formate and $\left[{ }^{14} \mathrm{C}\right]$ adenine.

\begin{tabular}{|c|c|c|c|c|}
\hline \multirow{2}{*}{ Cell type } & \multicolumn{4}{|c|}{ Treatment } \\
\hline & none & RNase & DNase & hot PCA \\
\hline \multicolumn{5}{|c|}{ Labeling with $\left[{ }^{14} \mathrm{C}\right]$ formate } \\
\hline Cortical thymocytes & $H$ & + & $(+)$ & $(+)$ \\
\hline Erythroblasts & m & m & $(+)$ & $(+)$ \\
\hline Myelocytes & + & + & $(+)$ & $(+)$ \\
\hline Reticulum cells & + & + & $(+)$ & $(+)$ \\
\hline \multicolumn{5}{|c|}{ Labeling with $\left[{ }^{14} \mathrm{C}\right]$ adenine } \\
\hline Cortical thymocytes & $H$ & + & + & : \\
\hline Erythroblasts & $(+)$ & $(+)$ & $(+)$ & . \\
\hline Myelocytes & 曲 & m & $(+)$ & $\cdot$ \\
\hline Reticulum cells & 冊 & 世 & $(+)$ & $\therefore$ \\
\hline $\begin{array}{l}\text { 0-No labeling } \\
(+) \text {-Very weak labeling } \\
+- \text { Weak labeling }\end{array}$ & \multicolumn{3}{|c|}{$\begin{array}{l}\text { \#-Marked labeling } \\
W-\text { Strong labeling } \\
W \text {-Intense labeling }\end{array}$} & \\
\hline
\end{tabular}


both, which were carried out with DNase. RNase or hot perchloric acid treatment, respectively, as shown in Table 1 .

It is interesting to compare the results of the present experiments with those of earlier studies on lymphoid cells in which $\left[{ }^{3} \mathrm{H}\right] \mathrm{d}$ Thd and $\left[{ }^{3} \mathrm{H}\right] \mathrm{dCyd}$ were used as DNA precursors. As mentioned in the Introduction, cortical thymocytes and germinal-center cells are much more heavily labeled with $\left[{ }^{3} \mathrm{H}\right] \mathrm{dCyd}$ than with $\left[{ }^{3} \mathrm{H}\right] \mathrm{dThd}$, whereas pyroninophilic blast cells or immunoblasts exhibit far stronger labeling with $\left[{ }^{3} \mathrm{H}\right] \mathrm{dThd}$ than with $\left[{ }^{3} \mathrm{H}\right] \mathrm{dCyd}$. The results of the present and earlier studies are summarized in Table 2. It can be seen from this table that there are considerable variations in the labeling patterns of blood-forming cells as depending on differences in the cell types as well as in the radioactive DNA precursors used. A combination for labeling any one cell type with any one of the isotopic markers by which DNA labeling is achieved to the greatest extent is as follows: pyroninophilic blast cells with $\left[{ }^{3} \mathrm{H}\right] \mathrm{dThd}$; cortical thymocytes, germinal-center cells and bone marrow lymphocytes with $\left[{ }^{3} \mathrm{H}\right] \mathrm{dCyd}$; erythroblasts with $\left[{ }^{14} \mathrm{C}\right]$ formate; and myelocytes, premonocytes and reticulum cells with $\left[{ }^{14} \mathrm{C}\right]$ adenine.

These findings are of particular interest for providing new criteria by which to identify the cell types of blood-forming cells. As an example, it is interesting to note that the few small round cells resembling erythroblasts, which occasionally occurred within the hepatic sinusoids as small cell clusters, revealed strong DNA labeling with $\left[{ }^{14} \mathrm{C}\right]$ formate but no such labeling with $\left[{ }^{14} \mathrm{C}\right]$ adenine. For this reason, such cells may be regarded as true erythroblasts which had emigrated from the bone marrow or spleen to the hepatic sinusoids. Another example is that some cell types of the connective tissue which were as

Table 2. The relative intensity of DNA labeling in vivo of blood-forming cells with radioactive DNA precursors.

\begin{tabular}{|c|c|c|c|c|}
\hline \multirow{2}{*}{ Classification of cells } & \multicolumn{4}{|c|}{ Radioactive DNA precursor } \\
\hline & {$\left[{ }^{3} \mathrm{H}\right] \mathrm{dThd}$} & {$\left[{ }^{3} \mathrm{H}\right] \mathrm{dCyd}$} & {$\left[{ }^{14} \mathrm{C}\right]$ formate } & {$\left[{ }^{14} \mathrm{C}\right]$ adenine } \\
\hline \multicolumn{5}{|l|}{ Lymphocytic series } \\
\hline Cortical thymocytes & + & 世 & + & + \\
\hline Germinal-center cells & + & m & + & + \\
\hline Bone marrow lymphocytes & + & m & + & + \\
\hline $\begin{array}{l}\text { Pyroninophilic blast cells } \\
\text { (Immunoblasts) }\end{array}$ & 世 & + & $?$ & $?$ \\
\hline \multicolumn{5}{|l|}{ Erythrocytic series } \\
\hline Eartly erythroblasts & + & H & W & $(+)$ \\
\hline Late erythroblasts & + & $H$ & H & $(+)$ \\
\hline \multicolumn{5}{|l|}{ Granulocytic series } \\
\hline Early myelocytes & $H$ & + & + & m \\
\hline Late myelocytes & $H$ & + & + & 册 \\
\hline \multicolumn{5}{|l|}{ Monocytic series } \\
\hline Premonocytes & $?$ & $?$ & + & m \\
\hline Reticulum cellsc) & $?$ & $?$ & + & 世 \\
\hline $\begin{array}{l}(+) \text {-Very weak labeling } \\
+ \text {-Weak labeling }\end{array}$ & $\begin{array}{l}\text { H-Marked } \\
\text { W-Strong }\end{array}$ & $\begin{array}{l}\text { ling } \\
\text { ing }\end{array}$ & & \\
\hline
\end{tabular}


heavily labeled with $\left[{ }^{14} \mathrm{C}\right]$ adenine as were the reticulum cells of the spleen and lymph nodes but were unlabeled with $\left[{ }^{14} \mathrm{C}\right]$ formate, occurred in fairly large numbers in the lamina propria of the intestinal villi as well as in the interstitial spaces of the kidney. This indicates that the observed cell types are similar to reticulum cells insofar as their labeling patterns with $\left[{ }^{14} \mathrm{C}\right]$ adenine and $\left[{ }^{14} \mathrm{C}\right]$ formate are concerned, and it raises the important question of whether such cell types should be considered as true reticulum cells or not. Accordingly, further studies on such cell types from other approaches are now being undertaken in our laboratory; namely, examinations of their phagocytic ability, peroxidase reactivity and other metabolic activities, as well as electron microscopic observations.

From the biochemical viewpoint, the results of the present experiments are also worthy of notice. It has been reported by several authors that the incorporation of $\left[{ }^{3} \mathrm{H}\right] \mathrm{dTh}$ or $\left[{ }^{3} \mathrm{H}\right] \mathrm{dCyd}$ into DNA is not a measure of the absolute rate of DNA synthesis (Nygaard and Potter, 1959; Hofert and White, 1968; Osogoe and Ueki, 1970 ; Osogoe et al., 1973; Osogoe and Miyamoto, 1979b; Osogoe and Okada, 1980). A similar result was obtained in the present experiments; it was clearly demonstrated that the patterns of DNA labeling with $\left[{ }^{14} \mathrm{C}\right]$ formate of blood-forming cells, erythroblasts and reticulum cells in particular, differed to a large extent from the corresponding patterns with $\left[{ }^{14} \mathrm{C}\right]$ adenine. The mechanisms by which such differences arise are complicated and will be discussed in a subsequent paper.

\section{Acknowledgement}

The authors wish to express their thanks to Dr. Minoru Amano, Department of Zoology, Faculty of Integrated Arts and Sciences, Hiroshima University, for his kind advice and assistance in performing DNase and RNase treatments of the sections and smears.

\section{References}

1) Amano, M.: Improved techniques for the enzymatic extraction of nucleic acid from tissue sections. J. Histochem. Cytochem., 10: 204-212, 1962.

2) Amano, M. and Osogoe, B.: Autoradiographic study on DNA synthesis in lymphoid tissues of the rat using tritiated thymidine and deoxycytidine. Cell Struct. Funt., 1: 81-92, 1975.

3) Brosh, S., Boer, P., Kupfer, B., de Vries, A. and Sperling, O.: De novo synthesis of purine nucleotides in human peripheral blood leukocytes. J. Clin. Invest., 58 : 289-297, 1976.

4) Hoffert, J.F. and White, A.: Effect of a single injection of cortisol on the incorporation of ${ }^{3} \mathrm{H}$-thymidine and ${ }^{3} \mathrm{H}$ deoxycytidine into lymphatic tissue DNA of adrenalectomized rats. Endocrinology, 82: 767-776, 1968.

5) Lajtha, L.G.: Utilization of formate- ${ }^{14} \mathrm{C}$ for synthesis of deoxyribonucleic acid by human bone marrow cells in vitro. Nature, 174 : 1013-1014, 1954.

6) Nygaard, O.F. and Potter, R. L.: Effect of $\mathrm{X}$-radiation on DNA metabolism in various tissues of the rat. Radiat. Res., 10: 462-476, 1959.

7) Osogoe, B. and Miyamoto, H.: The patterns of labeling of plasma cells and pyroninophilic blast cells with tritiated deoxycytidine and thymidine. Okajimas Folia Anat. Jpn., 55: 301-312, 1979a.

8) Osogoe, B. and Miyamoto, H.: Patterns of thymocyte labeling in vitro with tritiated thymidine and deoxycytidine, with special reference to competitive incorporation of the two deoxyribonucleosides. Okajimas Folia Anat. Jpn., 56: 81-90, 1979b.

9) Osogoe, B. and Okada, T.: The patterns of in vitro labeling of bone marrow lymphocytes and antibody-producing cells with tritiated thymidine and deoxycytidine: difference between the two cell 
types. Okajimas Folia Anat. Jpn., 57 : 89-96, 1980.

10) Osogoe, B., Tyler, R.W. and Everett, N.B.: The patterns of labeling of of germinal-center cells with tritiated deoxycytidine. J. Cell Biol., $57: 215-220$, 1973.

11) Osogoe, B. and Ueki, A.: A radioautographic study of the utilization of deoxycytidine for the formation of deoxyribonucleic acid-thymine in lymphocytes. J. Cell Biol., 46: 403-405, 1970.

12) Thomas, D. and Lochte, H. L., Jr. : Deoxyribonucleic acid synthesis by bone marrow cells in vitro. Blood, 12: 1086-
1095, 1957.

13) Totter, J.R.: Incorporation of isotopic formate into the thymine of bone marrow deoxyribonucleic acid in vitro. J. Am. Chem. Soc., 76 : 2196-2197, 1954.

14) Schwarzmeier, J.D.: Studies on purine de novo synthesis and cyclic AMP in normal and pathologic leukocytes. Wien Klin. Wochensch., 86: 716-724, 1974.

15) Scott, J. L.: Human leukocyte metabolism in vitro. I. Incorporation of adenine-8$\mathrm{C}^{14}$ and formate- $\mathrm{C}^{14}$ into the nucleic acids of leukemic leukocytes. J. Clin. Invest., 41 : 67-79, 1962. 


\section{Explanation of Figures}

\section{Plate I}

Fig. 1. Autoradiographs of splenic red pulp from rats injected with $\left[{ }^{14} \mathrm{C}\right]$ formate. $\times 300$.

A. Dense aggregations of intensely labeled erythroblasts. Control without treatment.

B. Labeling pattern of erythroblast aggregations corresponding to that shown in Fig. 1A, after treatment with RNase. Note that the label of the erythroblasts remains essentially unaltered and the silver grains become more distinctly localized over the nuclei of these cells than previously.

C. Labeling pattern of erythroblast aggregations corresponding to that shown in Fig. 1A, $\mathrm{B}$, after treatment with DNase. The label of these cells has disappeared to a large extent.

D. Labeling pattern of a portion of the splenic red pulp corresponding to that shown in Fig. 1A-C, after treatment with hot $10 \%$ perchloric acid. The label of the erythrolosts has disappeared completely. Silver grains are diffusely scattered over the tissue in smaller amounts than in the cases shown in Fig. 1A-C. 


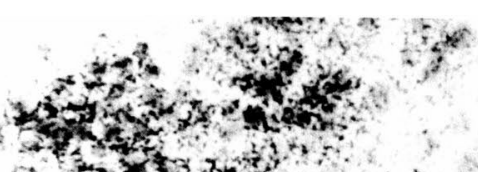

vit

704 and

$+x_{0}+3,2$

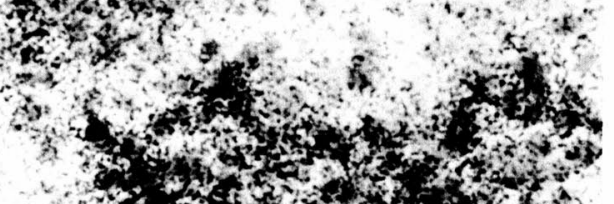

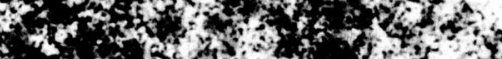

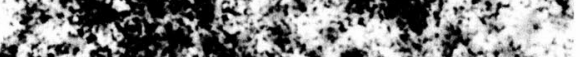
$4 x+2,0+3+4$

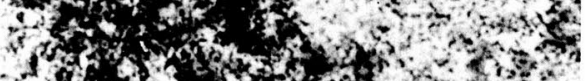

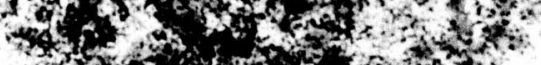

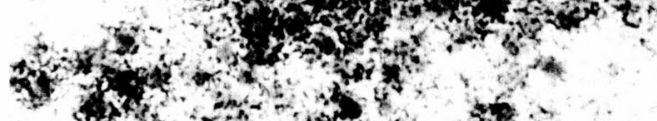

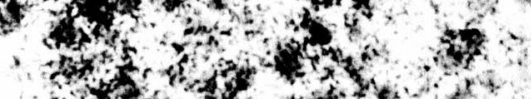

tis

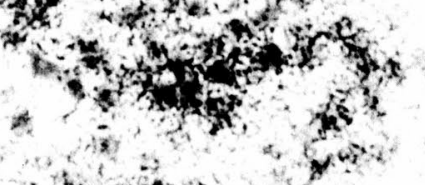

$$
\begin{aligned}
& 1,+x^{2} x
\end{aligned}
$$

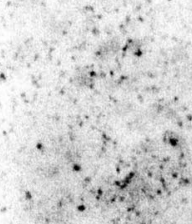

$8 \because \because 58$

w. $4: 4 \cdot 3$

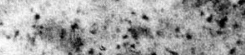

w. 60,2

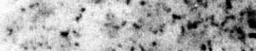

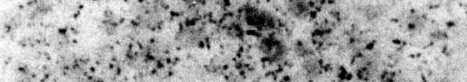

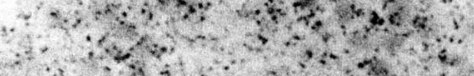

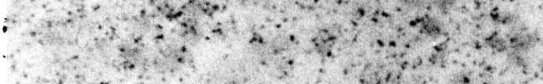

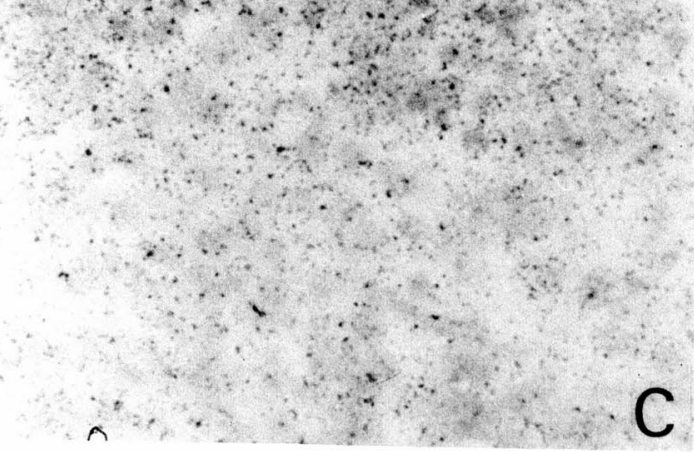

B. Osogoe and M. Yanagi $x^{2}+2 y^{2}+2$

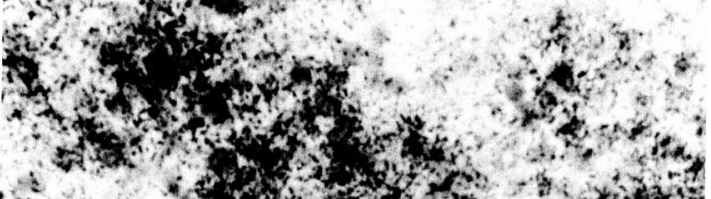



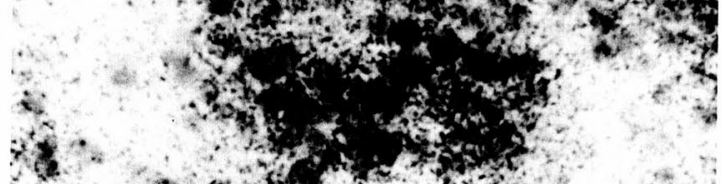

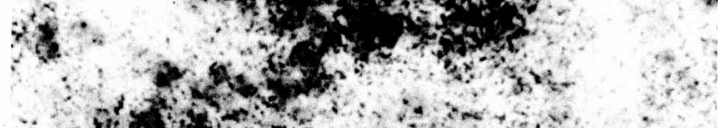

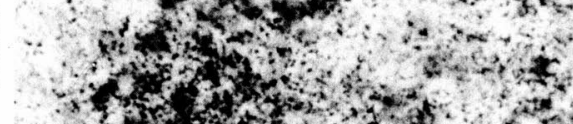

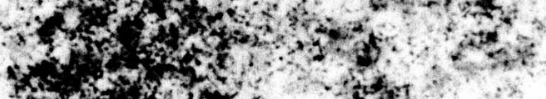

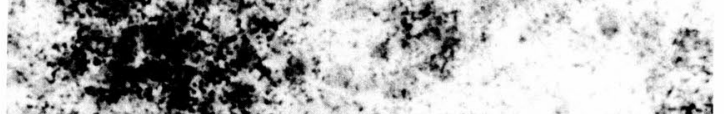
$x_{x \rightarrow 0}^{x} x^{2}+t^{2}$ $\therefore+4$

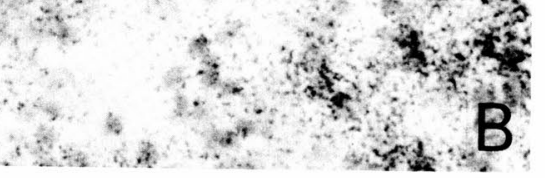

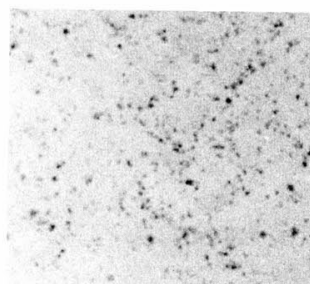




\section{Plate II}

Fig. 2. Autoradiographs of smear preparations of the thymus, lymph nodes and bone morrow from rats injected with $\left[{ }^{14} \mathrm{C}\right]$ formate. Labeling patterns after RNase treatment. $\times 750$.

A. Labeling pattern of thymic lymphocytes. The majority of the cells are weakly labeled.

B. Labeling pattern of lymh-node lymphocytes. The majority of the cells are unlabeled except for a few weakly labeled ones.

C. Labeling pattern of bone marrow cells. Note that the erythroblasts, particularly those at the polychromatic and orthochromatic stages, are intensely labeled in contrast to the weaker labeling of myelocytes having ring-form nuclei. 

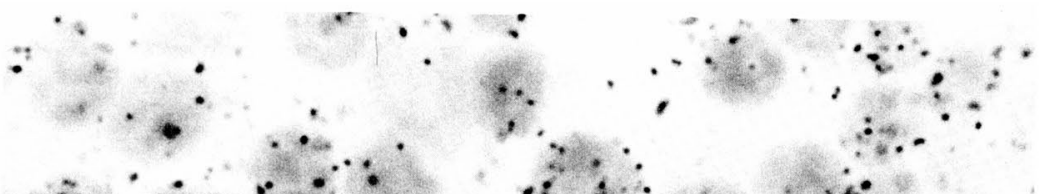

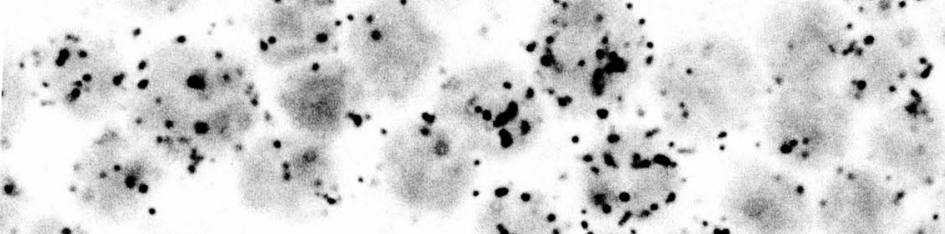

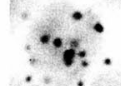

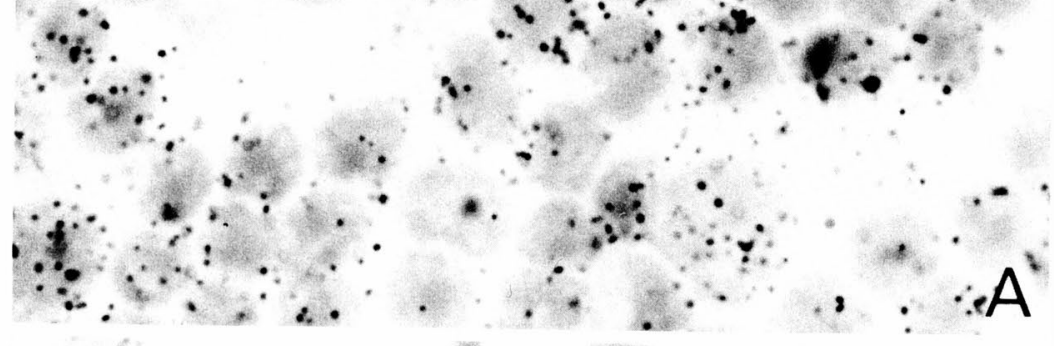

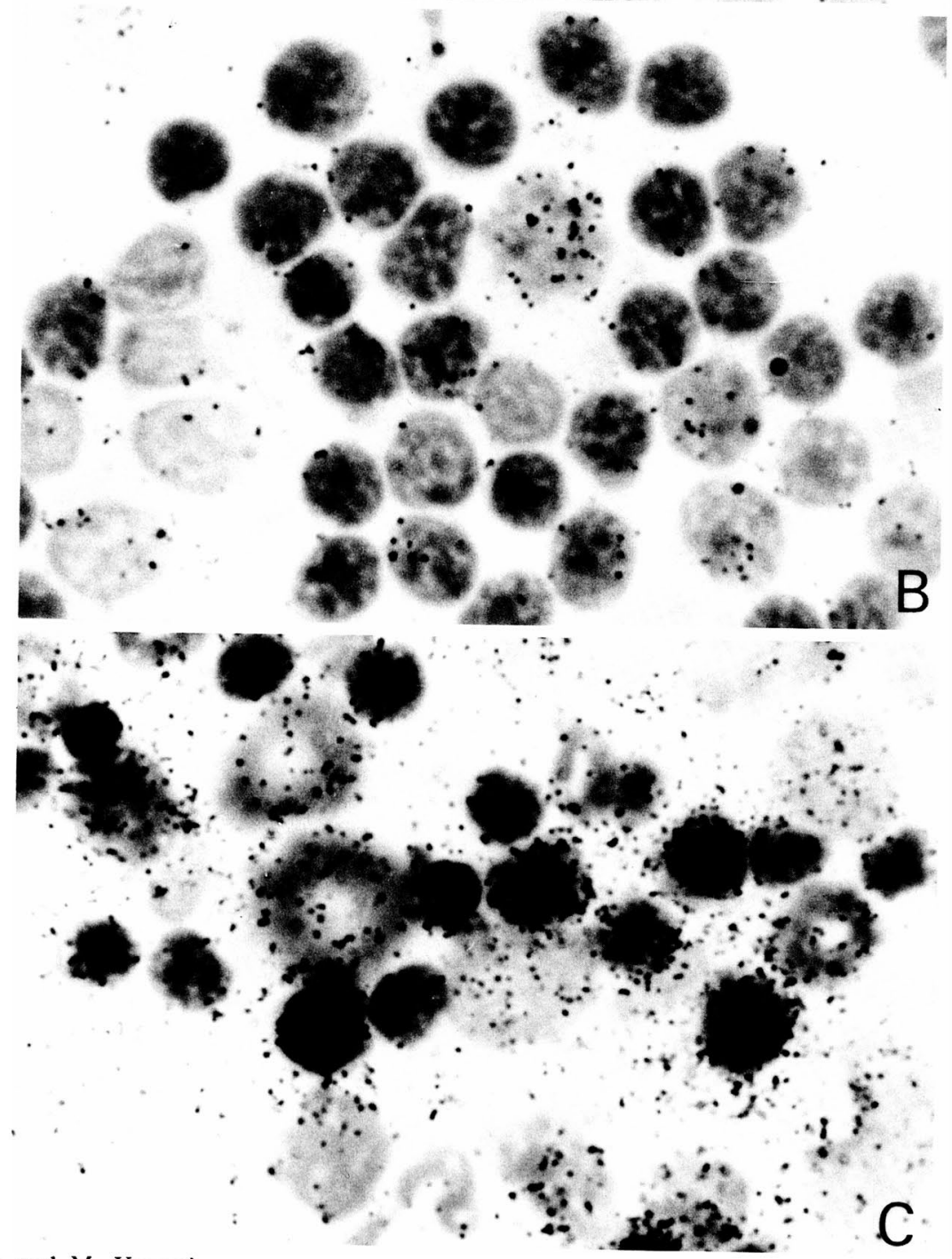

B. Osogoe and M. Yanagi 


\section{Plate III}

Fig. 3. Autoradiographs of bone marrow smears from rats injected with $\left[{ }^{14} \mathrm{C}\right]$ adenine. Labeling patterns after RNase treatment. $\times 750$.

a. Two heavily labeled myelocytes of relatively small size.

b. Two weakly labeled myelocytes of relatively large size.

c. An intensely labeled cell of relatively small size which may be regarded as a monoblast.

d. A moderately labeled premonocyte. 

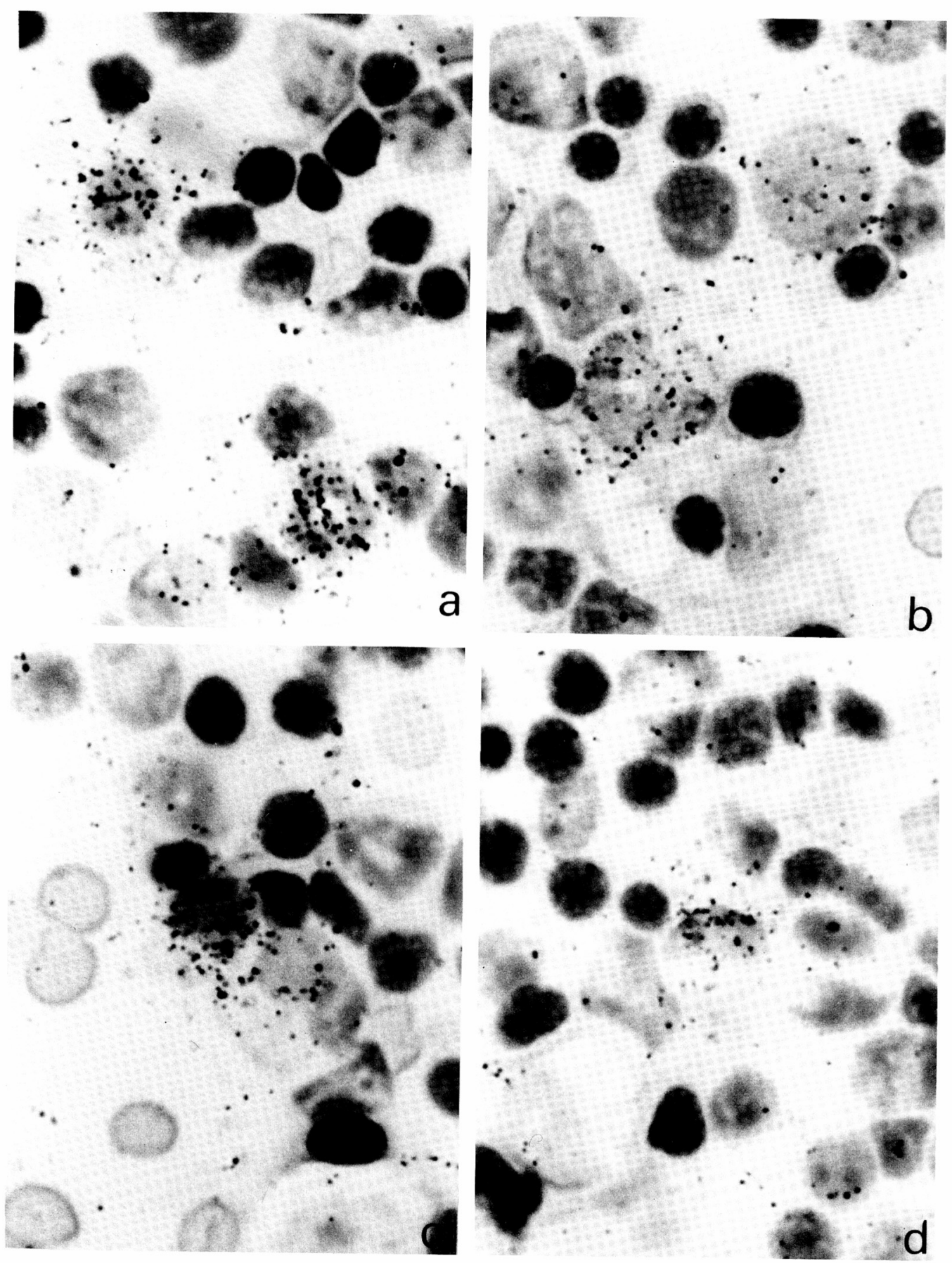

B. Osogoe and M. Yanagi 


\section{Plate IV}

Fig. 4. Autoradiographs of splenic white pulp from rats injected with $\left[{ }^{13} \mathrm{C}\right]$ adenine. $\times 300$.

A. Labeling pattern of the white pulp, illustrating four strongly labe led reticulum cells occurring in the marginal zone. The other cells including lymphocytes are weakly labeled. Control without treatment.

B. Labeling patterns of the white pulp after RNase treatment. Note the two intensely labeled reticulum cells. The label of other cell types disappeared to a large extent.

C. Labeling pattern of the white pulp after DNase treatment. In the marginal zone, silver grains are found in greater numbers than in the case of RNase treatment. The label of the reticulum cells has disappeared almost completely.

D. Autoradiographic picture of the portion corresponding to that shown in Fig. 1C, after treatment with hot $10 \%$ perchloric acid. No silver grains are apparent anywhere. 


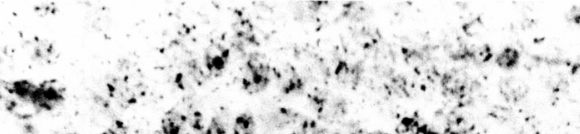

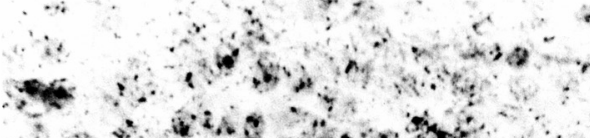

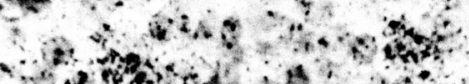

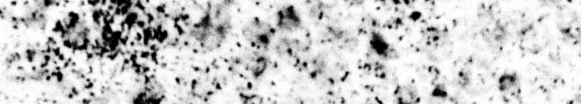

$4 x^{2}+2^{2}+2$

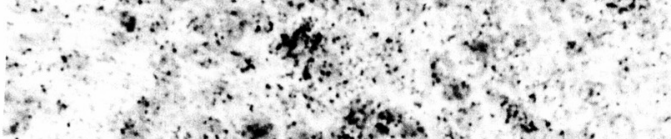

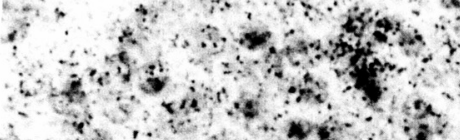

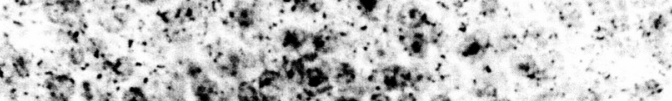

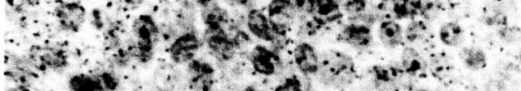

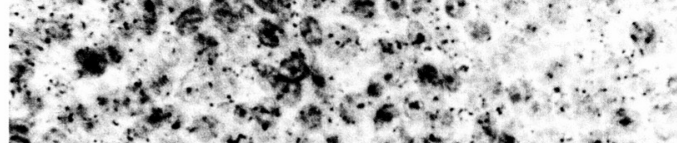

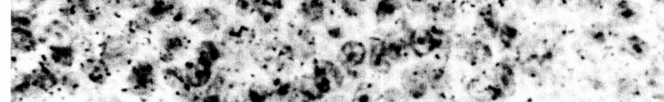

\section{le $\quad \ldots+x^{2} x^{2}+5$}

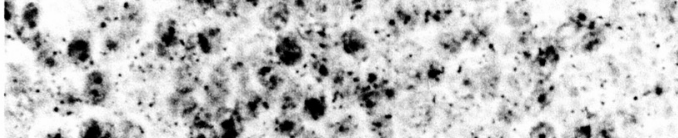

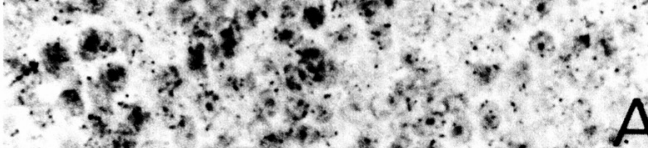

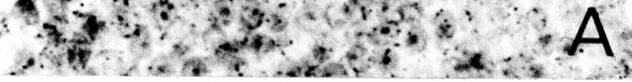

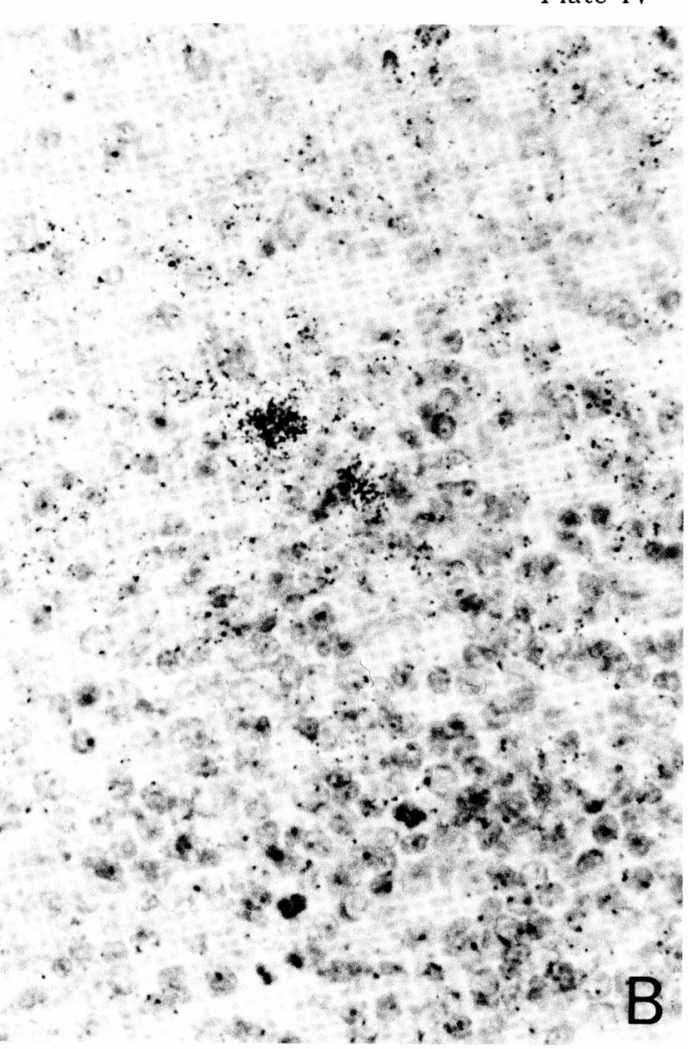

